Сероклин Л. В., здобувач Міжнародний науково-технічний університет імені академіка Юрія Бугая м. Київ, Украӥна

DOI: https://doi.org/10.30525/978-9934-26-080-3-6

\title{
СЕРЕДОВИЩЕ РИЗИКІВ РЕАЛІЗАЦІЇ ПАРТНЕРСТВА БІЗНЕСУ ТА ВЛАДИ У ФОРМІ КОНЦЕСІЇ В НАЦІОНАЛЬНИХ УМОВАХ РОЗВИТКУ
}

Актуалізація проблематики налагодження партнерських відносин між бізнесом і владою зумовлена низкою ризикових аспектів, які виникають в ході реалізації проєктів концесії.

Так, на ризики реалізації договорів концесії вказують у своїх дослідженнях фахівці 3 різних наукових сфер - економіки, державного управління, юридичних наук.

В цілому, якщо узагальнити погляди на ризики, що можуть проявлятися в ході реалізації концесії, то їх доцільно представити 
на трьох можливих рівнях. Саме ці рівня сприйняття ризиків від концесії формують відповідні елементи середовища для практичної реалізації концесійних договорів.

У таблиці 1 представлено загальні погляди на можливий прояв відповідних ризиків.

Таблиця 1

Можливі ризикові в реалізації концесійних договорів

\begin{tabular}{|c|c|}
\hline $\begin{array}{c}\text { Рівень дії / } \\
\text { прояву наслідків }\end{array}$ & Характеристика прояву \\
\hline Для державної влади & $\begin{array}{l}\text { - послаблення контролю за приватними } \\
\text { компаніями-операторами щодо вилучення моно- } \\
\text { польної ренти, орієнтованими на прибуток; } \\
\text { - можливе зростання цін для забезпечення } \\
\text { окупності інвестиційної програми; } \\
\text { - можливість прояву негативних соціальних } \\
\text { наслідків для споживачів, та зниження довіри } \\
\text { населення до місцевих органів влади внаслідок } \\
\text { банкрутства приватної компанії }\end{array}$ \\
\hline $\begin{array}{c}\text { Для місцевої влади / } \\
\text { територіальної } \\
\text { громади }\end{array}$ & $\begin{array}{l}\text { - можливість втрати контролю за зростанням } \\
\text { тарифів у разі прагнення концесіонера макси- } \\
\text { мізувати прибутки; } \\
\text { - послаблення контролю за поточною діяльністю } \\
\text { приватних компаній-операторів; } \\
\text { - можливість втрати контролю за об'єкти } \\
\text { державних природних монополій, землі внас- } \\
\text { лідок отримання їх у користування приватним } \\
\text { учасником }\end{array}$ \\
\hline $\begin{array}{c}\text { Для приватного } \\
\text { учасника договору } \\
\text { від бізнесу }\end{array}$ & $\begin{array}{l}\text { - високі ризики вкладень у будівництво і } \\
\text { розвиток інфраструктуру; } \\
\text { - можливе виникнення проблем тарифного } \\
\text { регулювання та ціноутворення; } \\
\text { - ризики невиконання зобов'язань державним } \\
\text { учасником внаслідок дефіциту бюджету; } \\
\text { - можливе повне чи часткове недотримання } \\
\text { державним учасником умов договору концесії; } \\
\text { - можливість втрати об’єкта у разі зміни } \\
\text { кон'юнктури ринку }\end{array}$ \\
\hline
\end{tabular}

Джерело: складено за [1-3] 
Разом 3 тим, серед окремих ризикових аспектів, які виникатимуть із можливих прогалин законодавчого забезпечення концесії у літературі вирізняють наступні [4, с. 174-175]:

- проблеми у процедурі виділення земельних ділянок для проєктів концесії. Так, для переможця конкурсу з концесії виділення земельної ділянки має бути здійснено автоматично, але у даному разі може виникати незаконне припинення права власності та права користування земельною ділянкою без рішення суду, якщо земельна ділянка потрібна для здійснення концесійної діяльності, але перебуває у власності суб'єкта, що не погоджується надати іï для реалізації концесійного проекту» [4, c. 174];

- можливість зловживання окремими нормами законодавства при внаслідок існування можливості обрання концесіонера за результатами прямих переговорів з концесієдавцем;

- можливість передавати майно у складі концесії в оренду. До орендованих об'єктів передачі концесіонеру окремих частин цілісних майнових комплексів, зокрема ліній зв'язку, інженерні комунікації електро-, тепло-, водо-, газопостачання. Така ситуація може створювати низку зловживань у оренді держмайна до 50 років, які є цікавими з економічної точки зору приватному суб'єкту. Цей аспект містить суттєві ризики, оскільки дає змогу зацікавленим особам в правовій площині оптимізувати свою діяльність без врахування інтересів розвитку держави.

Таким чином, окреслене дає підстави відзначити необхідність удосконалення середовища для практичної реалізації концесії в Україні, що може стати напрямом збалансування інтересів держави, місцевих органів влади та приватного бізнесу.

\section{Література:}

1. Гура О.Л. Концесія як форма залучення приватних інвестицій. Зовнішня торгівля: економіка, фінанси, право. 2013. № 1. С.112-117.

2. Єлісєєва Л.В. Муніципальна власність: економічний зміст та перспективи іiі трансформації в Україні в контексті світового досвіду. 
Ефективна економіка. 2012. №12. URL: http://www.economy.nayka.com.ua/ ?op $=1 \& \mathrm{z}=1317$.

3. Пархоменко С. П. Концесія як ефективний засіб залучення інвестицій у комунальне господарство. Інвестиціӥ: практика та досвід. 2012. № 12. С. 51-53.

4. Труба B.I., Завертнева-Ярошенко В.А. Розвиток концесійного законодавства України в контексті євроінтеграційних процесів. Часопис Київського університету права. 2018. № 4. С. 170-176. 